\title{
Incidence and factors associated with COVID-19 in 13 hemodialysis units
}

\author{
Javier L. Deira Lorenzo ${ }^{1}$ ( ) Silvia González Sanchidrián ${ }^{1}$. André Rocha Rodrigues ${ }^{1} \cdot$ Rosa M. Ruiz-Calero Cendrero $^{2}$. \\ Miguel A. Suarez Santisteban ${ }^{3}$. José M. Sánchez Montalbán ${ }^{1}$ · Josefa Galán González ${ }^{4}$. Olga Sánchez García ${ }^{5}$. \\ María T. Hernández Moreno ${ }^{6}$. Juan Villa Rincón ${ }^{7}$. María A. Fernández Solís ${ }^{8}$. Clarencio Cebrián Andrada ${ }^{9}$. \\ Gaspar Tovar Manzano ${ }^{10}$. Vanesa García-Bernalt Funes ${ }^{3} \cdot$ Alejandro Cives Muiño $^{11}$. Pedro Dorado Hernández ${ }^{12}$
}

Received: 8 February 2021 / Accepted: 6 June 2021 / Published online: 18 June 2021

(c) The Author(s), under exclusive licence to Springer Nature B.V. 2021

\section{Editor,}

We have read with great interest the most important manuscripts published in Int Urol Nephrol on COVID-19 in hemodialysis (HD) patients [1-5]. As so, we can provide our experience presenting an observational, prospective, multicenter study in a cohort of 668 HD patients from 6 hospital units and 7 peripheral HD centers, obtained between March 11th and April 17th of 2020. In this study, we analyzed the data from all the Rt-PCR collected in all HD units in Extremadura (Spain). The territorial scope exceeds one million people, and the data cover both healthcare settings: hospital and peripheral HD clinics (out-of-hospital).

We studied the incidence of COVID-19 in HD patients, the clinical characteristics, the factors related to the infection and the profitability of the diagnosis by Rt-PCR in this population. The number of tests done has to be considered in the context of the first wave of the pandemic in which the magnitude of the health crisis in general population limited the availability of the tests, making its optimization

Javier L. Deira Lorenzo

javierlorenzo.deira@salud-juntaex.es

1 Hospital San Pedro de Alcántara, Avda Pablo Naranjo S/N, 10.003 Cáceres, Spain

2 Hospital Universitario de Badajoz, Av. de Elvas, s/n, 06080 Badajoz, Spain

3 Hospital Virgen del Puerto, Paraje Valcorchero, S/N, 10600 Plasencia, Cáceres, Spain

4 FMC Badajoz, Av. Manuel Saavedra Martínez, 1A, 06006 Badajoz, Spain

5 FMC Mérida, Complejo Empresarial Carrión. Avda. Portugal s/n, 06800 Mérida, Badajoz, Spain

6 FMC Cáceres, Ronda de San Francisco, 10002 Cáceres, Spain essential. The average number of extractions was 2.6 a day, with a maximum peak of 8 extractions on March 24th. A total of 99 Rt-PCRs were performed in the study period; $14.8 \%(99 / 668)$ of the prevalent HD patients were analyzed using this test. This percentage was higher in hospitals compared to peripheral centers $(24.4 \%$ vs. $10.8 \%)$. $58.6 \%(58 / 99)$ of the samples were obtained in patients with suspected COVID-19 symptoms, the rest were taken from asymptomatic patients. $18.2 \%$ of the samples were positive (18/99), a percentage that rises to $25.9 \%(15 / 58)$ in symptomatic patients and falls to $7.3 \%$ (3/41) in asymptomatic patients. $72.2 \%(13 / 18)$ of positive samples were from the province of Cáceres (which includes 2 hospital units and 4 peripheral HD centers), where the infection rate among the general population was higher. Cough was the main predictive symptom ( $p=0.013)$, however, including all the parameters in a multivariate analysis, we did not find any variable that reached statistical significance. The incidence of confirmed cases showed an increasing trend between March 13th and April 11th, slowing down in the ultimate week, possibly

7 Hospital de Zafra Ctra, Badajoz-Granada, s/n, 06300 Zafra, Badajoz, Spain

8 FMC Villanueva, C/Doñana, s/n, Urbanización Los Pinos, 06700 Villanueva de la Serena, Badajoz, Spain

9 FMC Navalmoral, Ctra. Madrid-Lisboa, 29, 10300 Nalvalmoral de la Mata, Cáceres, Spain

10 FMC Coria, Polígono Ind. Los Rosales-Naves A-B. Planta $1^{\mathrm{a}}$, 10800 Coria, Cáceres, Spain

11 FMC Plasencia, Plaza del Olivar, 10600 Plasencia, Cáceres, Spain

12 Departamento de Terapéuticas Médicas Quirúrgicas, Universidad de Extremadura, Avda. Virgen del Puerto, 10600 Plasencia, Cáceres, Spain 
due to the very restrictive measures adopted by the Spanish government. The prevalence was $2.7 \%$ (18/668), with marked variability between hospital and peripheral units and between different health areas. Due to the high percentage of positive patients who were asymptomatic, $7 \%$ in our study and up to $40 \%$ in others [6], probably both the incidence of confirmed cases and prevalence of COVID-19 in our units are likely to be higher than the rates detected, given the fact that Rt-CRP was not determined in all of patients for the above-mentioned reasons. Nevertheless, the data from our study confirm the tendency known from other studies in our setting [6-10]. This study reflects the exposure and initial management of the pandemic in a region of Spain, which was one of the most severely affected European countries, together with Italy, at the beginning of the pandemic.

Funding No funding was received.

\section{Declarations}

Conflict of interest Authors declare no competing financial interests in relation to the article and its content.

Ethical approval This article does not contain any studies with animals performed by any of the authors. All procedures performed in studies involving human participants were in accordance with the ethical standards of the institutional and/or national research committee and with the 1964 Helsinki declaration and its later amendments or comparable ethical standards.

Informed consent Informed consent was exceptionally exempted by the Clinical Research Ethical Committee during the COVID-19 pandemic.

\section{References}

1. Zeng X, Huang X, Xu L et al (2020) Clinical outcomes of dialysis patients with COVID-19 in the initial phase of the COVID-19 outbreak in Wuhan, China. Int Urol Nephrol. https://doi.org/10. 1007/s11255-020-02670-0

2. Henry BM, Lippi G (2020) Chronic kidney disease is associated with severe coronavirus disease 2019 (COVID-19) infection. Int Urol Nephrol 52:1193-1194. https://doi.org/10.1007/ s11255-020-02451-9

3. Yamada T, Mikami T, Chopra N et al (2020) Patients with chronic kidney disease have a poorer prognosis of coronavirus disease 2019 (COVID-19): an experience in New York City. Int Urol Nephrol 52:1405-1406. https://doi.org/10.1007/ s11255-020-02494-y

4. Chen G, Hu R, Wang Y et al (2020) Recommendation from Peking Union Medical College Hospital for urgent hemodialysis during the COVID-19 pandemic. Int Urol Nephrol 52:1809-1810. https://doi.org/10.1007/s11255-020-02532-9

5. Shang W, Li Y, Li H et al (2020) Correlation between laboratory parameters on admission and outcome of COVID-19 in maintenance hemodialysis patients. Int Urol Nephrol. https://doi.org/10. 1007/s11255-020-02646-0

6. Sánchez-Pérez P, González-Calero P, Poma-Saavedra FH et al (2020) Results of a healthcare organization model for COVID-19 on hemodialysis in a tertiary hospital and its subsidized centers. Nefrologia 40(4):453-460. https://doi.org/10.1016/j.nefro.2020. 05.006

7. Arenas MD, Crespo M, Pérez-Sáez MJ et al (2020) Clinical profiles in renal patients with COVID-19. J Clin Med 9(8):2665. https://doi.org/10.3390/jcm9082665

8. Trujillo H, Caravaca-Fontán F, Sevillano Á et al (2020) SARSCoV-2 infection in hospitalized patients with kidney disease. Kidney Int Rep 5(6):905-909. https://doi.org/10.1016/j.ekir.2020.04. 024

9. Goicoechea M, Sánchez Cámara LA, Macías N et al (2020) COVID-19: clinical course and outcomes of 36 hemodialysis patients in Spain. Kidney Int 98(1):27-34. https://doi.org/10. 1016/j.kint.2020.04.031

10 Albalate M, Arribas P, Torres E et al (2020) Grupo enfermería HUIL. High prevalence of asymptomatic COVID-19 in haemodialysis: learning day by day in the first month of the COVID-19 pandemic. Nefrologia 40(3):279-286. https://doi.org/10.1016/j. nefro.2020.04.005

Publisher's Note Springer Nature remains neutral with regard to jurisdictional claims in published maps and institutional affiliations. 